\title{
Kaitan Karakteristik Kepala Rumah Tangga dengan Kemiskinan Anak di Nusa Tenggara Barat pada Tahun 2019
}

\author{
(The Relationship of Household Head's Characteristics with Child Poverty in West Nusa Tenggara
} at 2019)

\author{
Suci Ramadhanty ${ }^{1 *}$, Hardius Usman ${ }^{2}$ \\ 1,2 Politeknik Statistika STIS \\ Jalan Otto Iskandardinata No. 64C Jakarta Timur \\ E-mail: ${ }^{1 *} 111810616 @$ stis.ac.id, ${ }^{2}$ Hardius@ stis.ac.id
}

\begin{abstract}
ABSTRAK
Kemiskinan menyebabkan efek negatif bagi anak, baik jangka pendek maupun jangka panjang yang beresiko merampas masa depan mereka. Nusa Tenggara Barat (NTB) merupakan salah satu provinsi yang memiliki angka kemiskinan yang tinggi, dan kelompok umur yang paling beresiko untuk miskin adalah anak-anak. Penelitan ini bertujuan untuk mengetahui kaitan karakteristik Kepala Rumah Tangga (KRT) dengan kemiskinan anak di NTB pada tahun 2019. Penelitian ini menggunakan data Susenas Maret tahun 2019. Dengan menggunakan metode analisis Regresi Logistik Biner, penelitian ini menemukan bahwa, jumlah Anggota Rumah Tangga (ART), jenis kelamin KRT, status pekerjaan KRT, dan tingkat pendidikan KRT berhubungan signifikan dengan kemiskinan anak. Penelitian ini juga mengungkapkan bahwa, kemiskinan cenderung lebih besar terjadi pada anak yang tinggal bersama KRT dengan jumlah ART > 4 orang, KRT perempuan, KRT tidak bekerja, dan KRT berpendidikan rendah.
\end{abstract}

Kata kunci: Kemiskinan Anak, Regresi Logistik Biner, Karakteristik KRT, NTB

\section{ABSTRACT}

Poverty causes negative effects for children, both in the short and long term which risk depriving them of their future. West Nusa Tenggara (NTB) is one of the provinces that has a high poverty rate, and the age group most at risk for poverty is children. This study aims to study the relationship of household head's characteristics on child poverty in ntb at 2019. This study uses the March 2019 Susenas data. By using the Binary Logistics Regression analysis method, this study finds that the number of Household Members, gender of household heads, employment status of household heads, and education level of household heads have significantly related with child poverty. This study also revealed that poverty tends to be greater in children living with household heads with the number of household members > 4 people, female household heads, household heads who don't work, and household heads with low education.

Keywords: Child Poverty, Binary Logistics Regression, Household Head's Characteristics, NTB

\section{PENDAHULUAN}

Kemiskinan merupakan salah satu masalah mendasar yang dihadapi oleh setiap negara di dunia. Kemiskinan sering dihubungkan dengan ketidakmampuan seseorang dalam memenuhi kebutuhan maupun haknya. Ketidakmampuan akibat kemiskinan tentu memberi penderitaan bagi orang-orang yang terlibat didalamnya, penderitaan yang dialami tidak hanya secara fisik, tetapi secara psikologis atau mental juga (Kumala, Agustini, \& Rais, 2013). Dampak kemiskinan tidak hanya pada orang dewasa, melainkan pada anakanak juga. Kemiskinan pada anak bahkan lebih berdampak dari pada orang dewasa. Kemiskinan pada anak menyebabkan penderitaan, baik secara fisik maupun mental anak, baik jangka pendek maupun jangka panjang yang terus menumpuk sepanjang hidup anak. BPS (2017) menyatakan bahwa kemiskinan dapat memengaruhi mental, fisik, emosi, dan tingkat spiritual anak. Ortiz et al. (2012) menyatakan bahwa kemiskinan pada anak dapat dirasakan sepanjang hidup mereka (Ramadhani \& Munandar, 2019). Kumala, Agustini, dan Rais (2013) juga menyatakan bahwa kemiskinan pada anak bersifat kerusakan jangka panjang. Selain itu, anak-anak yang miskin juga lebih beresiko untuk menjadi orang dewasa yang miskin dan meneruskan kemiskinan itu ke generasi berikutnya (Casimiro et al.,2013 dalam Sari, 2018; Ramadhani \& Munandar, 2019; BPS, 2017).

Oleh karena itu, pengentasan kemiskinan pada anak perlu untuk dilakukan. Upaya ini sejalan dengan tujuan pembangunan baik secara global maupun nasional. Salah satu target global Sustainable Development Goals (SDGs) adalah mengurangi setidaknya setengah proporsi laki-laki, perempuan dan anak-anak dari semua usia, yang hidup dalam kemiskinan di semua dimensi kemiskinan pada tahun 2030. Pengentasan kemiskinan pada anak juga perlu dilakukan karena keberadaan anak sangatlah penting bagi masyarakat dan bangsa. Anak-anak adalah generasi penerus dari suatu bangsa, yang masa depan bangsa akan sangat 
dipengaruhi oleh kondisi anak-anak bangsa (BPS, 2017; UU No. 35 tahun 2014). Selain itu, bebas dari kemiskinan merupakan hak anak yang termuat dalam UU No. 35 tahun 2014 tentang perlindungan anak.

Nusa Tenggara Barat (NTB) adalah salah satu Provinsi yang tidak terlepas dari masalah kemiskinan, khususnya masalah kemiskinan pada anak. Hal ini dibuktikan oleh gambar 1 dibawah ini yang menunjukkan bahwa NTB memiliki jumlah penduduk miskin yang selalu tinggi dibanding nasional dari tahun 2015 sampai tahun 2019.

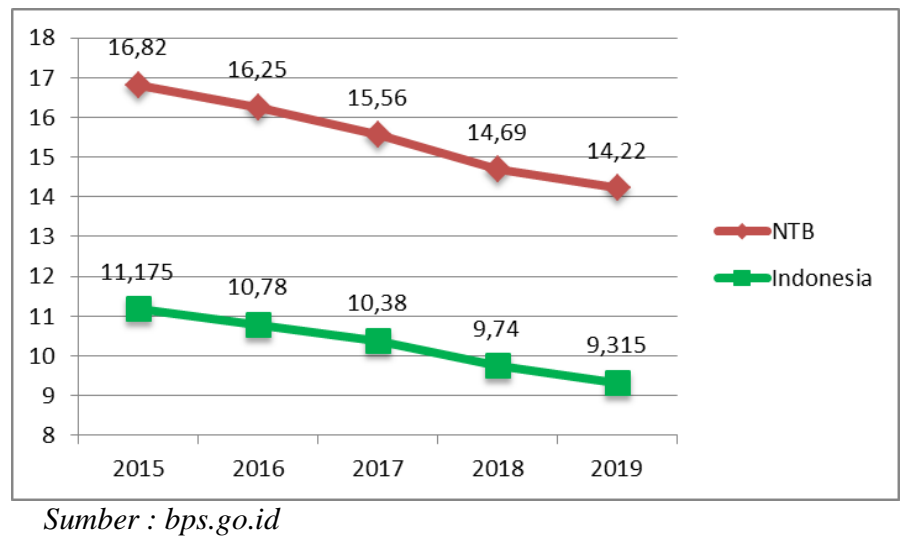

Gambar 1. Persentase penduduk miskin di NTB dan di Indonesia maret tahun 2015-2019

Tingginya persentase penduduk miskin di NTB menjadi indikasi awal tingginya juga persentase anak miskin di Provinsi tersebut. Hal ini disebabkan persentase kemiskinan pada kelompok usia anak lebih tinggi dari pada persentase kemiskinan pada kelompok usia selain anak. Hal ini dibuktikan oleh gambar 2 dibawah ini yang menunjukkan bahwa persentase kemiskinan pada penduduk usia anak lebih tinggi dari pada persentase kemiskinan pada penduduk usia selain anak di Indonesia. Sehingga, apabila kondisi tersebut dikaitkan dengan Provinsi NTB yang memiliki masalah kemiskinan yang selalu tinggi dalam 5 tahun terakhir, dapat disimpulkan bahwa ada masalah kemiskinan anak di Provinsi tersebut.

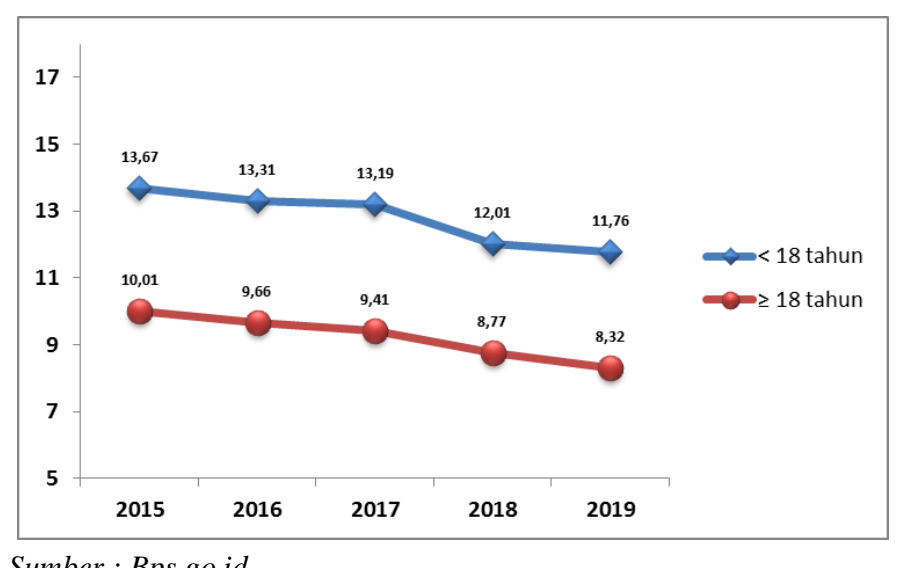

Gambar 2. Persentase penduduk yang hidup di bawah garis kemiskinan nasional menurut kelompok umur Maret Tahun 2015-2019 di Indonesia

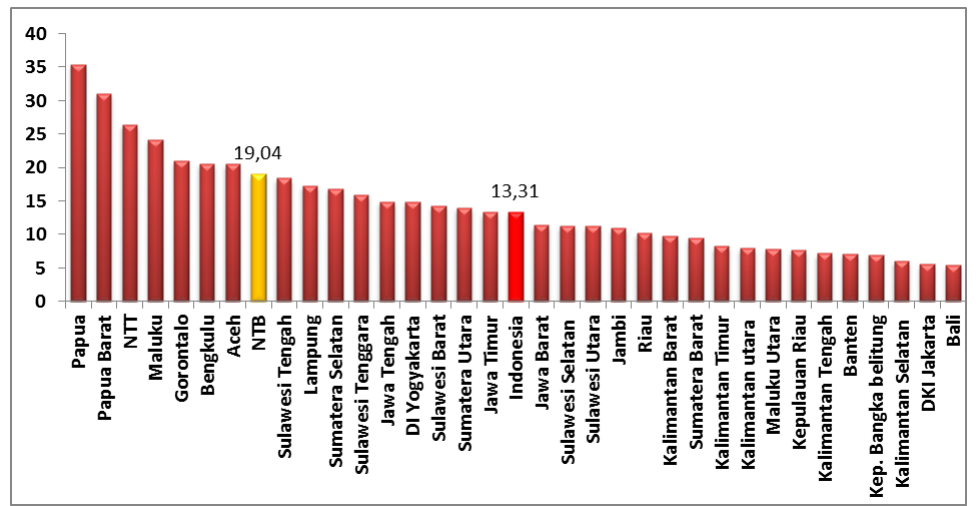

Sumber: Publikasi BPS

Gambar 3. Persentase anak miskin menurut provinsi tahun 2016 
Hal ini diperkuat oleh data pada Gambar 3 yang memperlihatkan bahwa, pada tahun 2016 persentase anak miskin di NTB adalah sebesar 19,04 persen. Angka ini melebihi persentase anak miskin nasional yang hanya sebesar 13,31 persen. Angka 19,04 persen ini juga menempatkan NTB sebagai provinsi dengan urutan tertinggi ke-8 dalam hal persentase kemiskinan anak pada tahun 2016.

Segala pihak yang terkait baik orang tua, pemerintah maupun masyarakat semestinya saling bekerja sama untuk mengurangi kemiskinan pada anak. Hal ini dikarenakan, undang-undang telah memberi amanah untuk bertanggung jawab dalam pemenuhan dan perlindungan kebutuhan dan hak anak (UU No. 35 tahun 2014). Salah satu upaya dalam menanggapi masalah ini adalah dengan melakukan penelitian. Penelitian yang dilakukan diharapkan dapat dijadikan referensi bagi pemerintah untuk mengurangi masalah kemiskinan pada anak dan diharapkan pula dapat dijadikan bahan pembelajaran bagi pembaca dan peneliti sendiri.

Ada beberapa penelitian terkait yang meneliti masalah kemiskinan pada anak. Penelitian-penelitian ini menganalisis hubungan kemiskinan anak dengan karakteristik KRT. Penelitian Dewi (2019) menyatakan bahwa banyaknya jumlah tanggungan KRT dan status pekerjaan KRT berhubungan signifikan dengan kemiskinan anak tahun 2019. Selain itu, ada juga penelitian Smay (2017) yang menyatakan bahwa umur KRT, jenis kelamin KRT, pendidikan KRT, status perkawinan KRT, jenis pekerjaan KRT dan jumlah jam kerja KRT berhubungan signifikan dengan kemiskinan anak di Provinsi Papua pada tahun 2015. Penelitian Sari (2018) juga menyatakan bahwa status perkawinan KRT, status bekerja KRT, dan jumlah anak dalam rumah tangga berhubungan signifikan dengan kemiskinan anak di Provinsi Banten tahun 2017. Oleh sebab itu, dengan mempertimbangkan ketersediaan data dan kemampuan peneliti, penelitian ini menggunakan umur KRT, jumlah ART, jenis kelamin KRT, status perkawinan KRT, status pekerjaan KRT dan tingkat pendidikan KRT sebagai variabel bebas, dengan hipotesis penelitian adalah keenam variabel bebas tersebut secara masingmasing memiliki hubungan signifikan dengan kemiskinan anak di Provinsi NTB pada tahun 2019. Diharapkan, dengan dilakukannya penelitian ini, didapat informasi mengenai gambaran umum kemiskinan anak serta keterkaitannya dengan karakteristik kepala rumah, variabel-variabel yang memiliki hubungan signifikan dengan kemiskinan anak serta kecenderungan dari masing-masing variabel bebas yang berhubungan signifikan dengan kemiskinan anak di Provinsi NTB pada tahun 2019.

\section{METODOLOGI}

\section{Landasan teori}

Kemiskinan adalah ketidakmampuan seseorang dalam memenuhi kebutuhan dasar minimum. BPS (2017) menyatakan bahwa kemiskinan anak merupakan keadaan tidak tercukupinya semua kebutuhan dasar anak. Hak dasar anak yang tidak terpenuhi, seperti makanan dan minuman yang layak, pendidikan, kesehatan, perumahan yang baik, akses informasi dan sebagainya. Jadi, kemiskinan anak adalah kondisi kemiskinan yang terjadi pada anak yang menyebabkan anak tidak terpenuhi kebutuhan/hak dasarnya. Dalam artian lain anak miskin adalah anak yang tidak mendapatkan hak dasarnya baik dari aspek ekonomi maupun dari aspek lainnya.

Menurut Word Bank (2005), kemiskinan dikategorikan kedalam tiga karakteristik penyebab utama yang memengaruhinya. Yang pertama regional-level caharacteristics, yaitu penyebab kemiskinan yang berhubungan dengan karakteristik wilayah. Kemudian yang kedua, community-level caharacteristics, yaitu penyebab kemiskinan yang dikaitkan dengan karateristik masyarakat. Dan yang ketiga, household and individual-level caharacteristics, yaitu penyebab kemiskinan yang dihubungkan dengan karakteristik rumah tangga dan individu. Karakteristik rumah tangga dan individu dalam berbagai penelitian sering dikaitkan dengan Karakteristik KRT. Ada beberapa penelitian internasional yang meneliti kaitan karakteristik KRT dengan kemiskinan. Sakuhuni, Chidoko, Dhoro, dan Gwaindepi (2011) di Zimbabwe dalam penelitiannya, menyatakan bahwa jenis kelamin KRT, umur KRT, ukuran rumah tangga, tingkat pendidikan tertinggi KRT, status perkawinan KRT berhubungan signifikan dengan kemiskinan. Selanjutnya ada juga penelitian Jan, Chishti, dan Eberle (2009) di Pakistan yang menyatakan bahwa ukuran rumah tangga, umur KRT, dan lama sekolah KRT berhubungan signifikan dengan kemiskinan. Hasil yang sama juga ditemukan oleh Albert dan Collado (2004) di Filipina yang menyatakan bahwa pendidikan tertinggi KRT, status perkawinan KRT, jenis kelamin KRT, dan umur KRT berhubungan signifikan dengan kemiskinan (Usman, Agustina, \& Parwanto, 2019).

Dalam penelitian ini, pengukuran kemiskinan anak berdasar pada metode yang digunakan oleh BPS. BPS mengukur kemiskinan dengan pendekatan moneter berdasarkan garis kemiskinan. BPS mengeluarkan garis kemiskinan provinsi NTB pada tahun 2019 di wilayah Perkotaan sebesar 396.696 per kapita per bulan dan diwilayah Perdesaan sebesar 374.123 per kapita per bulan. Menurut BPS (2017), cara mengukur kemiskinan adalah dengan membandingkan nilai rata-rata pengeluaran per kapita per bulan dengan garis kemiskinan. Nilai 
rata-rata pengeluaran per kapita per bulan diperoleh dengan mencari nilai total pengeluaran rumah tangga dibagi dengan jumlah anggota rumah tangganya. Jika suatu rumah tangga memiliki nilai rata-rata pengeluaran per kapita per bulan di bawah garis kemiskinan maka seluruh anggota rumah tangga dalam rumah tangga tersebut, termasuk anak yang tercakup didalamnya merupakan penduduk miskin.

\section{Cakupan Penelitian dan Metode Pengumpulan data}

Penelitian ini menggunakan satu variabel tak bebas yaitu status kemiskinan anak dan enam variabel bebas yaitu, umur KRT, jumlah ART, jenis kelamin KRT, status perkawinan KRT, status pekerjaan KRT dan tingkat pendidikan KRT. Unit analisis dalam penelitian ini adalah anak di NTB pada tahun 2019. Definisi anak dalam penelitian ini menggunakan konsep BPS, dimana anak didefinisikan sebagai penduduk yang berusia 0-17 tahun. Penelitian ini menggunakan data yang dikumpulkan pada tahun 2019, dengan jumlah sampel yang digunakan sebanyak 7846 anak.

Data yang digunakan dalam penelitian adalah data sekunder yang berasal dari Survei Sosial Ekonomi Nasional KOR (Susenas KOR) dan Susenas modul konsumsi/pengeluaran (Susenas KP) pada bulan maret tahun 2019 yang dikumpulkan oleh BPS. Dalam penelitian ini, Susenas KOR digunakan untuk mendapatkan data mengenai variabel bebas. Sedangkan susenas KP digunakan untuk mendapatkan data variabel tak bebas yaitu status kemiskinan anak.

\section{Metode analisis yang digunakan}

Metode analisis yang digunakan dalam penelitian ini ada dua, yaitu analisis deksriptif dan analisis inferensia. Analisis deskriptif berupa grafik, tabel dan peta tematik digunakan untuk mencapai tujuan penelitian yang pertama, yaitu mendapatkan gambaran umum kemiskinan anak di NTB pada tahun 2019. Sedangkan, analisis inferensia digunakan untuk mendapatkan tujuan penelitian yang kedua dan ketiga, yaitu mengetahui variabel bebas yang berhubungan signifikan dengan kemiskinan anak dan kecenderungan kemiskinan anak pada variabel bebas yang signifikan tersebut. Analisis inferensia menggunakan metode Regresi Logistik Biner. Adapun Bentuk umum model Regresi Logistik Biner adalah sebagai berikut :

$$
\pi(D)=\frac{\exp ^{\left(\beta_{0}+\beta_{1} \mathrm{D}_{1}+\cdots+\beta_{9} \mathrm{D}_{9}\right)}}{1+\exp \left(\beta_{0}+\beta_{1} \mathrm{D}_{1}+\cdots+\beta_{9} \mathrm{D}_{9}\right)}
$$

Fungsi $\pi(x)$ tidak linear dalam parameter. Sedangkan untuk melihat hubungan variabel bebas dan variabel tak bebas harus menggunakan fungsi yang linear. Oleh sebab itu, perlu dilakukan suatu transformasi logit. Adapun Bentuk umum model Transformasi logit $(g(D))$ adalah sebagai berikut:

$$
g(D)=\operatorname{Logit} \pi(D)=\ln \left[\frac{\pi(D)}{1-\pi(D)}\right]=\beta_{0}+\beta_{1} \mathrm{D}_{1}+\cdots+\beta_{9}
$$

Keterangan :

*) signifikansi pada taraf signifikan 5 persen.

$\beta_{0}, \beta_{1}, \ldots, \beta_{9}=$ Koefisien Regresi Logistik Biner

$\mathrm{D}_{1} \quad=$ Variabel dummy umur $\operatorname{KRT}(1: \geq 60$ tahun \& $0:<60$ tahun)

$\mathrm{D}_{2} \quad=$ Variabel dummy jumlah ART $(1:>4$ tahun $\& 0: \leq 4$ orang $)$

$\mathrm{D}_{3} \quad=$ Variabel dummy jenis kelamin KRT (1: Perempuan \& 0:Laki-laki)

$\mathrm{D}_{4} \quad=$ Variabel dummy KRT berstatus kawin (1: Cerai \& 0: Kawin)

$\mathrm{D}_{5} \quad=$ Variabel dummy KRT berstatus cerai (1: Belum Kawin \& 0:Kawin)

$\mathrm{D}_{6} \quad=$ Variabel dummy KRT bekerja di sektor informal (1:Iinformal \& 0 : Formal)

$\mathrm{D}_{7} \quad=$ Variabel dummy KRT tidak bekerja (1: Tidak Bekerja \& 0: Formal)

D $\quad=$ Variabel dummy KRT berpendidikan menengah (1: Pendidikan Menengah \& 0: Pendidikan Tinggi)

D $9 \quad=$ Variabel dummy KRT berpendidikan rendah (1: Pendidikan Rendah \& 0: Pendidikan Tinggi)

Setelah model terbentuk, tahapan analisis Regresi Logistik Biner adalah sebagai berikut :

\section{Estimasi parameter}

Metode estimasi parameter digunakan untuk mengestimasi nilai-nilai parameter yang belum diketahui. Pada Regresi Logistik Biner, metode estimasi yang digunakan adalah metode Maximum Likelihood Estimator 
(MLE). Metode ini menghasilkan estimator maksimum likelihood. Untuk mendapatkan nilai estimator tersebut perlu dilakukan diferensi $\mathrm{L}(\beta)$ terhadap $\beta$ dengan menggunakan metode iterasi menggunakan sofware statistik sehingga menghasilkan estimator yang digunakan untuk membentuk persamaan Regresi Logistik Biner. Persamaan Regresi Logistik Biner yang akan dibentuk adalah sebagai berikut :

$$
\hat{g}(D)=\widehat{\beta}_{0}+\widehat{\beta}_{1} \mathrm{D}_{1}+\cdots+\widehat{\beta}_{9} \mathrm{D}_{9}
$$

\section{Uji Kebaikan Model}

Penelitian ini menggunakan dua uji kebaikan model, yaitu uji Hosmer dan Lemeshow serta tabel klasifikasi. Uji Hosmer dan Lemeshow digunakan untuk melihat kecocokan model dalam menjelaskan status kemiskinan anak. Sedangkan nilai tabel klasifikasi digunakan untuk melihat kekuatan prediksi model dalam menjelaskan status kemiskinan anak.

\section{a. Uji Hosmer dan Lemeshow}

Adapun tahapan yang dilakukan dalam uji ini adalah sebagai berikut :

1. $\mathrm{H}_{0}$ : Model yang dibentuk fit (tidak ada perbedaan antara hasil prediksi model dengan hasil observasi)

$\mathrm{H}_{1}$ : Model yang dibentuk tidak fit (ada perbedaan antara hasil prediksi model dengan hasil observasi)

2. Tingkat signifikansi $(\alpha)=5$ persen

3. Statistik uji yang digunakan adalah statistik uji $\hat{\mathrm{C}}$

4. Keputusan Tolak $\mathrm{H}_{0}$ jika $\hat{\mathrm{C}}>\chi_{(0,05 ; g-2)}^{2}$ atau $p$-value $<0,05$

5. Jika keputusan yang diperoleh Tolak $\mathrm{H}_{0}$, maka model yang terbentuk tidak sesuai dalam menjelaskan status kemiskinan anak. Oleh sebab itu, diharapkan hasil yang diperoleh dalam uji ini adalah Gagal Tolak $\mathrm{H}_{0}$.

\section{b. Tabel Klasifikasi}

Merupakan ukuran yang digunakan untuk melihat kekuatan prediksi model Regresi Logistik Biner. Kekuatan prediksi tercermin dari seberapa efektif/tepat model yang telah terbentuk mampu menjelaskan status kemiskinan anak atau dalam artian lain menunjukkan seberapa besar tingkat kebenaran klasifikasi model. Kekuatan prediksi model ditunjukkan oleh nilai overall percentage. Nilai overall percentage yang semakin besar menunjukkan semakin baik model dalam memprediksi status kemiskinan anak yang sebenarnya.

\section{Pengujian Signifikansi Parameter Secara Simultan}

Pengujian ini dilakukan untuk mengetahui hubungan variabel-variabel bebas dengan variabel status kemiskinan anak secara bersamaan di dalam model. Pengujian ini menggunakan likelihood ratio test. Adapun tahapan pengujiannya adalah sebagai berikut :

1. H0 : $\beta_{0}=\beta_{1}=\ldots=\beta_{9}=0$ ( Tidak ada satupun variabel bebas yang berhubungan signifikan dengan kemiskinan anak )

H1 : minimal terdapat satu $\beta \mathbf{j} \neq 0$ ( Minimal ada satu variabel bebas yang berhubungan signifikan dengan kemiskinan anak), dimana $\mathrm{j}=1,2, \ldots, 9$

2. Tingkat signifikansi $(\alpha)=5$ persen

3. Statistik uji : uji G/Omnibus Test

4. Keputusan Tolak H0 jika Ghitung $>\chi_{(0.05,9)}^{2}$ atau $p$-value $<0.05$

5. Jika keputusan yang diperoleh adalah Tolak HO dapat disimpulkan bahwa, minimal ada satu variabel bebas yang berhubungan signifkan dengan kemiskinan anak di NTB pada tahun 2019

\section{Pengujian Signifikansi Parameter Secara Parsial}

Pengujian ini dilakukan untuk mengetahui hubungan dari tiap-tiap variabel bebas dengan kemiskinan anak di NTB pada tahun 2019. Adapun tahapan pengujiannya adalah sebagai berikut :

1. $\mathrm{H}_{0}: \beta_{j}=0$ (Variabel bebas ke-j tidak behubungan signifikan dengan kemiskinan anak)

$\mathrm{H}_{1}: \beta_{j} \neq 0$ ( Variabel bebas ke-j berhubungan signifikan dengan kemiskinan anak), dimana $\mathrm{j}=$ $1,2, \ldots, 9$

2. Tingkat signifikasi $(\alpha)=5$ persen 
3. Statistik uji : Wald Test

4. Keputusan Tolak $\mathrm{H}_{0}$ jika $W_{j}^{2}>\chi_{(0,05 ; 1)}^{2}$ atau nilai $p$-value $<0,05$

5. Jika keputusan yang diperoleh adalah Tolak $\mathrm{H}_{0}$, dapat disimpulkan bahwa, variabel bebas ke-j berhubungan signifikan dengan kemiskinan anak di NTB tahun 2019

\section{Interpretasi Parameter/ Interpretasi Odds Ratio}

Odds ratio adalah suatu ukuran yang mencerminkan seberapa besar kecenderungan kategori $\mathrm{x}=1$ mengalami $\mathrm{y}=1$ dibandingkan kategori $\mathrm{x}=0$. Nilai odds ratio, yaitu nilai dari $\exp \left(\hat{\beta}_{j}\right)$ pada variabel bebas yang signifikan memengaruhi status kemiskinan anak. Semakin besar nilai $\hat{\beta}_{j}$ mengindikasikan kecenderungan variabel bebas terhadap status kemiskinan anak juga semakin tinggi.

Tabel 1. Ringkasan kategori variabel bebas dan pembentukan dummy variabel

\begin{tabular}{|c|c|c|c|c|}
\hline $\begin{array}{c}\text { Nama } \\
\text { Variabel }\end{array}$ & Kategori & $\begin{array}{c}\text { Nilai } \\
\text { Dummy }\end{array}$ & $\begin{array}{l}\text { Variabel } \\
\text { Dummy }\end{array}$ & Cut Off \\
\hline (1) & (2) & (3) & (4) & $(5)$ \\
\hline \multirow{2}{*}{$\begin{array}{c}\text { Status } \\
\text { kemiskinan } \\
\text { anak }\end{array}$} & 1 : Tidak Miskin & 0 & - & $\begin{array}{c}\text { Pendapatan perkapita perbulan } \geq \text { garis } \\
\text { kemiskinan }\end{array}$ \\
\hline & 2 : Miskin & 1 & - & $\begin{array}{c}\text { Pendapatan perkapita perbulan }<\text { garis } \\
\text { kemiskinan }\end{array}$ \\
\hline \multirow{2}{*}{ Umur KRT } & $1:<60$ tahun & 0 & & $1-59$ tahun \\
\hline & $2: \geq 60$ tahun & 1 & $\mathrm{D}_{1}$ & Lainnya \\
\hline \multirow{2}{*}{ Jumlah ART } & $1: \leq 4$ Orang & 0 & - & 1-4 Orang \\
\hline & $2:>4$ Orang & 1 & $\mathrm{D}_{2}$ & Lainnya \\
\hline \multirow{2}{*}{$\begin{array}{l}\text { Jenis } \\
\text { Kelamin } \\
\text { KRT }\end{array}$} & 1 : Laki-Laki & 0 & - & Laki-laki \\
\hline & 2 : Perempuan & 1 & $\mathrm{D}_{3}$ & Perempuan \\
\hline Status & 1 : Kawin & 0 & - & Kawin \\
\hline \multirow{2}{*}{$\begin{array}{c}\text { Perkawinan } \\
\text { KRT }\end{array}$} & $2:$ Cerai & 1 & $\mathrm{D}_{4}$ & Cerai hidup/cerai mati \\
\hline & 3 : Belum Kawin & 1 & $\mathrm{D}_{5}$ & Belum Kawin \\
\hline \multirow{3}{*}{$\begin{array}{c}\text { Status } \\
\text { Pekerjaan } \\
\text { KRT }\end{array}$} & $1:$ Formal & 0 & - & $\begin{array}{c}\text { Berusaha dibantu buruh tetap/buruh dibayar dan } \\
\text { buruh/karyawan/pegawai }\end{array}$ \\
\hline & $2:$ Informal & 1 & $\mathrm{D}_{6}$ & Lainnya \\
\hline & 3 : Tidak bekerja & 1 & $\mathrm{D}_{7}$ & Tidak bekerja \\
\hline \multirow{3}{*}{$\begin{array}{c}\text { Tingkat } \\
\text { Pendidikan } \\
\text { KRT }\end{array}$} & 0 : Pendidikan Tinggi & 0 & - & Diploma/Sarjana/Magister/Spesialis/Doktor \\
\hline & $\begin{array}{l}1 \text { : Pendidikan } \\
\text { Menengah }\end{array}$ & 1 & $\mathrm{D}_{8}$ & SMP/SMA/Sederajat \\
\hline & 2: Pendidikan Rendah & 1 & $\mathrm{D}_{9}$ & Tidak sekolah/SD \\
\hline
\end{tabular}

\section{HASIL DAN PEMBAHASAN}

\section{Gambaran Umum Kemiskinan Anak di Provinsi Nusa Tengara Barat Pada Tahun 2019}

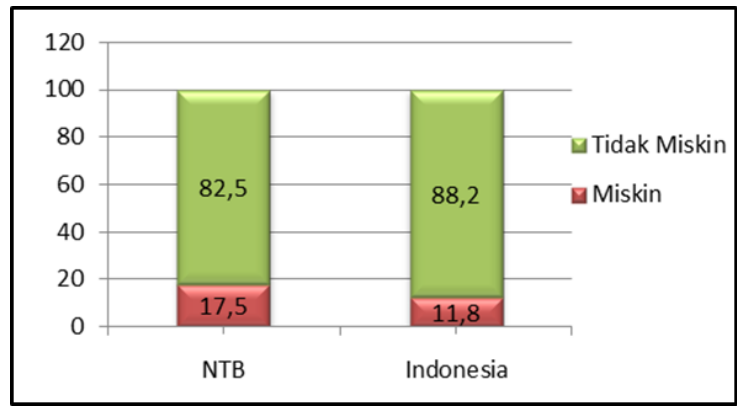

Sumber : Susenas KOR, susenas KP tahun 2019 (diolah) dan bps.go.id

Gambar 4. Persentase anak miskin di NTB dan Indonesia Maret tahun 2019

Gambar 4 diatas menunjukkan bahwa proporsi anak miskin di NTB lebih tinggi dari nasional. Gambar 4 menunjukkan bahwa dari 10 Kabupaten/Kota di NTB, 3 diantaranya memiliki angka kemiskinan terendah yaitu Kota Mataram, Kabupaten Lombok Barat dan Kabupaten Sumbawa Barat. Kebalikan dari itu, 3 
Kabupaten/Kota lainnya memiliki persentase kemiskinan terendah, yaitu Kabupaten Lombok Timur sebesar 23,5, Kabupaten Lombok Utara sebesar 21,3\% dan Kabupaten Dompu sebesar 22,7\%.

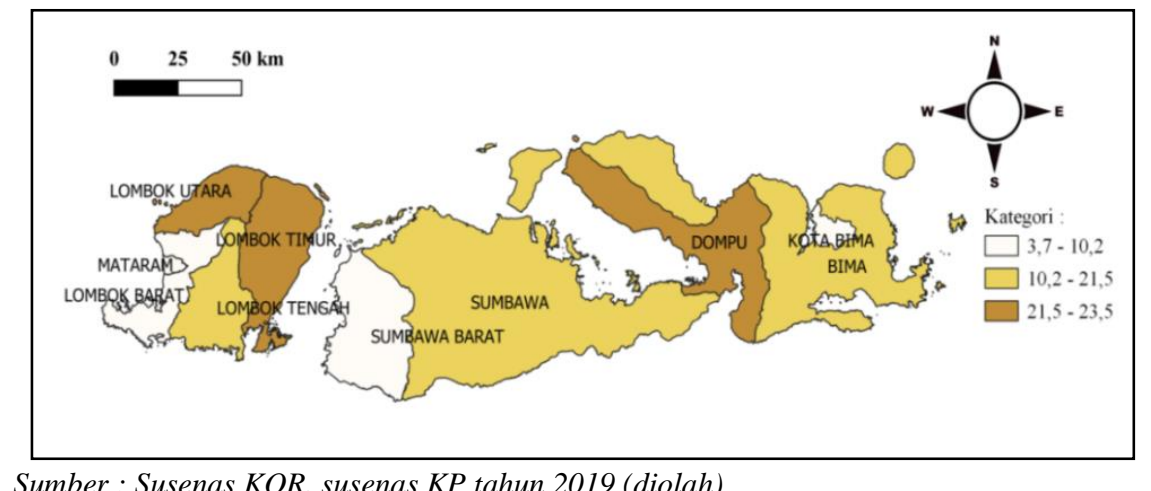

Gambar 5. Persentase anak miskin berdasarkan Kabupaten/Kota di NTB pada tahun 2019

Selanjutnya adalah gambaran umum kemiskinan anak berdasarkan karakteristik KRT. Tabel 2 dibawah ini menunjukkan bahwa KRT lansia, KRT yang memiliki ART $>4$ orang, KRT perempuan, KRT yang belum kawin, KRT yang tidak bekerja dan KRT yang berpendidikan rendah memiliki persentase kemiskinan anak yang lebih tinggi dari kategori lainnya didalam variabel yang sama.

Tabel 2 : Persentase kemiskinan anak menurut karakteristik KRT di NTB pada tahun 2019

\begin{tabular}{|c|c|c|c|c|c|}
\hline \multirow{2}{*}{ No } & \multirow{2}{*}{ Variabel } & \multirow{2}{*}{ Kategori } & \multirow{2}{*}{$\begin{array}{c}\text { Persetase } \\
\text { Total }\end{array}$} & \multicolumn{2}{|c|}{ Status Kemiskinan } \\
\hline & & & & Miskin & Tidak miskin \\
\hline (1) & (2) & (3) & & (4) & (5) \\
\hline \multirow{2}{*}{1} & \multirow{2}{*}{ Umur KRT } & Usia $<60$ tahun & 90,6 & 16,46 & 83,54 \\
\hline & & Usia $\geq 60$ tahun & 9,4 & 27,67 & 72,33 \\
\hline \multirow{2}{*}{2} & Jumlah Anggota Rumah & $\leq 4$ orang & 57,3 & 13,80 & 86,20 \\
\hline & Tangga & $>4$ orang & 42,77 & 22,48 & 77,52 \\
\hline \multirow{3}{*}{3} & \multirow{3}{*}{ Jenis Kelamin KRT } & Laki-laki & 82,59 & 16,21 & 83,79 \\
\hline & & Perempuan & 17,41 & 23,72 & 76,28 \\
\hline & & Kawin & 89,29 & 16,83 & 77,41 \\
\hline \multirow{3}{*}{4} & \multirow{2}{*}{ Status kawin KRT } & Cerai & 10,03 & 22,59 & 83,17 \\
\hline & & Belum kawin & 0,67 & 32,78 & 67,22 \\
\hline & \multirow{4}{*}{ Status bekerja KRT } & Bekerja di sektor formal & 9,72 & 7,68 & 92,32 \\
\hline \multirow[t]{3}{*}{5} & & Bekerja di sektor informal & 59,16 & 20,96 & 79,04 \\
\hline & & Tidak bekerja & 9,72 & 28,00 & 72,00 \\
\hline & & Tinggi & 9,58 & 6,11 & 93,89 \\
\hline \multirow{2}{*}{6} & Tingkat Pendidikan KRT & Menengah & 41,77 & 15,55 & 84,45 \\
\hline & & Rendah & 48,65 & 21,44 & 78,56 \\
\hline
\end{tabular}

Sumber : Susenas KOR, susenas KP tahun 2019 (diolah)

\section{Variabel-variabel yang memiliki hubungan signifikan dengan kemiskinan anak di provinsi nusa tenggara barat pada tahun 2019}

Tujuan ini diperoleh dengan menggunakan analisis Regresi Logistik Biner. Langkah pertama yang dilakukan dalam analisis Regresi Logistik Biner adalah menguji kebaikan model. Nilai statistik uji Ĉ pada uji Hosmer dan Lemeshow adalah sebesar 10,703 atau nilai $p$-value-nya adalah 0,152. Angka ini lebih besar dari taraf signifikansi 5 persen. Sehingga dapat diputuskan hasil pengujian Gagal Tolak $\mathrm{H}_{0}$. Dengan demikan dapat disimpulkan bahwa, dengan tingkat signifikansi 5 persen, model yang dibentuk cocok dalam menjelaskan status kemiskinan anak di NTB pada tahun 2019. Berikutnya, Dengan menggunakan cut of point sebesar 0,158, Nilai overall percentage pada tabel klasifikasi adalah sebesar 66\%. Angka ini menunjukkan bahwa model dapat mengklasifikasikan status kemiskinan anak secara keseluruhan dengan benar sebesar $66 \%$. Atau dalam artian lain model memiliki kekuatan prediksi sebesar $66 \%$.

Setelah pengujian kebaikan model dilakukan, langkah berikutnya adalah melakukan pengujian signifikansi parameter secara simultan. Nilai statistik uji $\mathrm{G}$ pada uji likelihood ratio adalah sebesar 448,211 atau nilai $p$-value-nya adalah sebesar 0,000. Angka ini lebih kecil dari tingkat signifikansi 5 persen yang artinya keputusan uji adalah Tolak $\mathrm{H}_{0}$. Dengan demikian, dapat disimpulkan bahwa dengan tingkat signifikansi 5 
persen, minimal ada satu variabel karakteristik KRT yang memiliki hubungan signifikan dengan kemiskinan anak di NTB pada tahun 2019.

Tabel 3. Hasil pengujian parsial dan estimasi parameter

\begin{tabular}{cccccc}
\hline Variabel Bebas & B & S.E. & Wald & Sig. & exp $\left(\widehat{\boldsymbol{\beta}}_{j}\right)$ \\
\hline $\mathrm{D}_{1}$ & $-0,002$ & 0,108 & 0,000 & 0,984 & \\
D $_{2}$ & $\mathbf{0 , 6 8 6}$ & $\mathbf{0 , 0 6 7}$ & $\mathbf{1 0 5 , 1 0 8}$ & $\mathbf{0 , 0 0 0}$ & $\mathbf{1 , 9 8 4 8}$ \\
$\mathrm{D}_{3}$ & $\mathbf{0 , 5 2 4}$ & $\mathbf{0 , 1 1 8}$ & $\mathbf{1 9 , 6 3 2}$ & $\mathbf{0 , 0 0 0}$ & $\mathbf{1 , 6 8 9}$ \\
$\mathrm{D}_{4}$ & 0,169 & 0,399 & 0,181 & 0,671 & \\
$\mathrm{D}_{5}$ & $-0,112$ & 0,409 & 0,075 & 0,785 & \\
$\mathrm{D}_{6}$ & $\mathbf{0 , 9 1 6}$ & $\mathbf{0 , 0 9 3}$ & $\mathbf{9 7 , 6 7 2}$ & $\mathbf{0 , 0 0 0}$ & $\mathbf{2 , 4 9 8}$ \\
D $_{7}$ & $\mathbf{1 , 2 0 1}$ & $\mathbf{0 , 1 3 3}$ & $\mathbf{8 2 , 0 7 7}$ & $\mathbf{0 , 0 0 0}$ & $\mathbf{3 , 3 2 4}$ \\
$\mathrm{D}_{8}$ & $\mathbf{0 , 7 2 0}$ & $\mathbf{0 , 1 7 5}$ & $\mathbf{1 6 , 8 3 6}$ & $\mathbf{0 , 0 0 0}$ & $\mathbf{3 , 3 2 4}$ \\
D $_{9}$ & $\mathbf{1 , 1 1 4}$ & $\mathbf{0 , 1 7 4}$ & $\mathbf{4 0 , 7 9 1}$ & $\mathbf{0 , 0 0 0}$ & $\mathbf{3 , 0 4 8}$ \\
\hline
\end{tabular}

Sumber : Susenas KOR, susenas KP tahun 2019 (diolah)

Setelah diperoleh keputusan Tolak H0 pada uji simultan, berikutnya dapat dilakukan uji signifikansi parameter secara parsial. Dari tabel 3, terlihat bahwa ada dua variabel bebas yang memiliki nilai p-value lebih besar sama dengan tingkat signifikansi 5 persen, yaitu variabel umur KRT dan variabel status kawin KRT. Variabel umur KRT memiliki p-value sebesar 0,984, yang berarti Gagal Tolak H0. Jadi, dapat disimpulkan bahwa dengan tingkat signifikansi 5 persen, variabel umur KRT tidak memiliki hubungan yang signifikan dengan kemiskinan anak di NTB pada tahun 2019. Hal ini berarti, peluang anak menjadi miskin dalam KRT lansia dan bukan KRT lansia tidak berbeda nyata. Kondisi ini menunjukkan bahwa, kemampuan KRT lansia di NTB secara ekonomi untuk menjaga anak-anak mereka jatuh ke jurang kemiskinan tidak berbeda dengan kemampuan KRT yang bukan lansia. Selain variabel umur, variabel status perkawinan KRT-Pun memiliki nilai p-value yang lebih besar dari tingkat signifikansi 5 persen, yang berarti Gagal Tolak H0. Jadi, dapat disimpulkan bahwa dengan tingkat signifikansi 5 persen, variabel status perkawinan KRT tidak berhubungan signifikan dengan kemiskinan anak di Nusa Tenggara Barat pada tahun 2019. Hal ini berarti, peluang anak menjadi miskin pada rumah tangga dengan KRT berstatus kawin, cerai, dan belum kawin tidak berbeda nyata. Kondisi ini menunjukkan bahwa, KRT yang mempunyai pasangan dan KRT yang melajang mempunyai kemampuan yang relatif sama untuk menjaga anak-anak mereka menjadi miskin.

Selanjutnya, untuk empat variabel lainnya memiliki nilai p-value yang lebih kecil dari taraf signifikan 5 persen. Jadi, dapat disimpulkan bahwa dengan tingkat signifikansi 5 persen, variabel jumlah ART, jenis kelamin KRT, status pekerjaan KRT dan tingkat pendidikan KRT secara masing-masing tidak berhubungan signifikan dengan kemiskinan anak di NTB pada tahun 2019. Tabel 3 diatas juga menampilkan nilai estimasi koefisien Regresi yang digunakan untuk membentuk persamaan Regresi Logistik Biner. Adapun persamaan yang terbentuk adalah sebagai berikut:

$$
\begin{array}{r}
\hat{g}(D)=-3,891-0,002 \mathrm{D}_{1}+0,686 \mathrm{D}_{2}+0,524 \mathrm{D}_{3}+0,169 \mathrm{D}_{4}-0,112 \mathrm{D}_{5}+ \\
0,916 \mathrm{D}_{6}+1,201 \mathrm{D}_{7}+0,720 \mathrm{D}_{8}+1,114 \mathrm{D}_{9} \ldots \ldots \ldots \ldots \ldots \ldots \ldots \ldots \ldots \ldots \ldots \ldots \ldots \ldots \ldots \ldots \ldots \ldots \ldots \ldots \ldots \ldots \ldots \ldots \ldots
\end{array}
$$

\section{Kecenderungan dari Masing-Masing Variabel Bebas yang Signifikan Memengaruhi Kemiskinan Anak di Nusa Tenggara Barat pada Tahun 2019}

Nilai odds Ratio pada variabel dummy jumlah ART adalah sebesar 1,985. Artinya anak yang tinggal bersama KRT yang memiliki ART > 4 orang cenderung 1,985 kali mengalami kemiskinan dibandingkan dengan anak yang tinggal dengan KRT yang memiliki ART $\leq 4$ orang dengan asumsi variabel lainnya konstan. Hal ini menunjukkan bahwa anak, yang tinggal bersama KRT yang memiliki jumlah ART yang lebih banyak lebih beresiko mengalami kemiskinan. Ini terjadi karena jumlah ART yang banyak menyebabkan semakin besarnya pendapatan yang dikeluarkan untuk biaya hidup karena banyaknya ART yang harus dipenuhi kebutuhannya (Chou, 2013 dalam Dewi, 2019).

Variabel dummy jenis kelamin KRT memiliki nilai odds ratio sebesar 1,689. Artinya anak yang tinggal bersama KRT perempuan cenderung 1,689 kali mengalami kemiskinan dibandingkan dengan anak yang tinggal bersama KRT laki-laki dengan asumsi variabel bebas lainnya konstan. Ini menunjukan bahwa, anak yang tinggal bersama KRT perempuan lebih beresiko mengalami kemiskinan. Todaro (2000) menyatakan, hal ini dapat terjadi karena pada umumnya, perempuan sulit mendapatkan pekerjaan dengan upah yang tinggi dibandingkan laki-laki. 
Kemudian, Nilai odds ratio dari variabel dummy KRT yang bekerja di sektor informal adalah sebesar 2,498. Artinya, anak yang tinggal bersama KRT yang bekerja di sektor informal cenderung 2,498 kali mengalami kemiskinan dibandingkan dengan anak yang tinggal dengan KRT yang bekerja disektor formal dengan asumsi variabel bebas lainnya konstan. Hal ini membuktikan bahwa anak yang tinggal bersama KRT yang bekerja di sektor informal lebih beresiko mengalami kemiskinan. Hasil ini sejalan dengan pendapat Todaro (2000) menyatakan bahwa produktivitas dan pendapatan mereka yang bekerja di sektor informal cenderung lebih rendah daripada pendapatan mereka yang bekerja disektor formal. Selanjutnya, nilai odds ratio dari variabel dummy KRT yang tidak bekerja adalah sebesar 3,324. Artinya, anak yang tinggal bersama KRT yang tidak bekerja cenderung 3,324 kali mengalami kemiskinan dibandingkan dengan anak yang tinggal dengan KRT yang bekerja disektor formal dengan asumsi variabel bebas lainnya konstan. Angka ini lebih tinggi dari kecenderungan kemiskinan yang terjadi pada KRT yang bekerja di sektor informal. Hal ini membuktikan bahwa anak yang tinggal bersama KRT yang tidak bekerja lebih beresiko mengalami kemiskinan dibandingkan KRT yang bekerja, baik di sektor formal maupun informal. Menurut sukirno (2012), hal ini dapat terjadi karena efek buruk tidak bekerja adalah ketiadaaan pendapatan yang menyebabkan rumah tangga kekurangan pendapatannya.

Nilai odds ratio dari variabel dummy KRT berpendidikan menengah adalah sebesar 2,054. Artinya, anak yang tinggal bersama KRT yang berpendidikan menengah cenderung 2,054 kali mengalami kemiskinan dibandingkan dengan anak yang tinggal dengan KRT yang berpendidikan tinggi dengan asumsi variabel bebas lainnya konstan. Sedangkan untuk nilai odds ratio dari variabel dummy KRT berpendidikan rendah adalah sebesar 3,048. Artinya, anak yang tinggal bersama KRT yang berpendidikan rendah cenderung 3,048 kali mengalami kemiskinan dibandingkan dengan anak yang tinggal dengan KRT yang berpendidikan tinggi dengan asumsi variabel bebas lainnya konstan. Kedua nilai odds ratio ini membuktikan bahwa, semakin rendah pendidikan KRT maka semakin tinggi kecenderungan anak yang tinggal bersama KRT tersebut mengalami kemiskinan. Menurut Sagir (1989) dalam Junaidi (2019) hal ini dapat terjadi karena proses pendidikan, pelatihan, dan pengembangan dapat meningkatkan produktifitas kerja dan meningkatkan kualitas hidup.

\section{KESIMPULAN}

Berdasarkan hasil dan pembahasan, maka kesimpulan yang dapat diambil adalah sebagai berikut. Analisis deskriptif menunjukkan hasil bahwa, proporsi jumlah anak miskin di Nusa Tenggara Barat pada tahun 2019 lebih tinggi dibanding nasional. Persentase kemiskinan anak berdasarkan jenis kelamin adalah seimbang. Kemudian, tiga kabupaten/kota yang memiliki persentase kemiskinan anak tertinggi adalah Kabupaten Lombok Utara, Kabupaten Lombok Timur dan Kabupaten Dompu. Selanjutnya, KRT yang berumur lansia, yang memiliki tanggungan $>4$ orang, yang berjenis kelamin perempuan, yang berstatus belum kawin, yang tidak bekerja dan berpendidikan rendah, memiliki persentase kemiskinan anak yang lebih tinggi dari kategori lainnya didalam variabel yang sama. Selanjutnya, berdasarkan hasil analisis inferensia pada uji parsial, variabel-variabel karakteristik KRT yang signifikan memengaruhi status kemiskinan anak di NTB pada tahun 2019 adalah variabel jumlah ART, jenis kelamin KRT, status pekerjaan KRT dan tingkat pendidikan KRT. Sedangkan dua variabel bebas lainnya, yaitu umur KRT dan status perkawinan KRT tidak signifikan memengaruhi status kemiskinan anak di NTB pada tahun 2019. Dan berdasarkan nilai odds ratio, kemiskinan cenderung lebih besar terjadi pada anak yang tinggal bersama KRT dengan jumlah ART > 4 orang, KRT perempuan, KRT yang tidak bekerja dan KRT yang berpendidikan rendah.

Berdasarkan kesimpulan yang telah diuraikan, peneliti mengajukan beberapa saran sebagai berikut. Pemerintah dapat meningkatkan taraf hidup KRT yang tidak bekerja dengan membuka lebih banyak lapangan kerja. Salah satu program yang dapat dilakukan adalah mendukung UMKM yang ada dalam masyarakat karena usaha ini menyerap banyak tenaga kerja. Selain itu, pemerintah juga harus dapat memaksimalkan potensi alam NTB yang terkenal memiliki beragam tempat wisata alam yang indah dan eksotis sebagai peluang terserapnya tenaga kerja lokal. Selanjutnya, pemerintah juga harus berupaya meningkatkan taraf hidup KRT yang bekerja di sektor informal dengan menyediakan lebih banyak program-program yang terjangkau untuk menambah keahlian, keterampilan dan kemampuan mereka. Kemudian, pemerintah juga harus berupaya meningkatkan taraf hidup KRT yang berpendidikan rendah dengan cara menyediakan lebih banyak beasiswa untuk anakanak mereka agar anak-anak mereka tidak merasakan hal yang sama seperti KRT yang berpendidikan rendah alami. Beasiswa tersebut dapat ditujukan untuk mereka yang tidak mampu secara ekonomi atau untuk mereka yang berprestasi. Selanjutnya, pemerintah juga dapat membangun lebih banyak sekolah dan perguruan tinggi yang terjangkau untuk masyarakat NTB. Terakhir, saran untuk peneliti selanjutnya adalah mengembangkan penelitian mengenai kemiskinan anak dengan cara menggunakan variabel bebas lainnya, atau dapat juga 
melakukan penelitian dengan variabel kemiskinan anak diukur dengan pendekatan non moneter atau multidimensi.

\section{UCAPAN TERIMA KASIH}

Penulis mengucapkan terima kasih kepada Dr. Erni Tri Astuti selaku Direktur Politeknik Statistika STIS, Agung Priyo Utomo, S.Si, M.T selaku Ketua Prodi DIII Statistik Politeknik Statistika STIS sekaligus dosen penguji, Dr. Hardius Usman, M. Si selaku dosen pembimbing, Dr. Rita Yuliana S.Si, M.S.E. selaku dosen penguji, orang tua, saudara-saudari dan teman-teman DIII Statistik angkatan 60.

\section{DAFTAR PUSTAKA}

Bachtiar, N., Rasbi, M. J., \& Fahmi, R. (2016). Analisis Kemiskinan Anak Balita Pada Rumah Tangga Di Provinsi Sumatera Barat. Jurnal Kependudukan Indonesia, 29-38.

Bappenas ."Mengakhiri Kemiskinan Dalam Segala Bentuk di Manapun." Bappenas . 2 Juni 2021. <http://sdgs.bappenas.go.id/tujuan-1/>

BPS. (2017). Analisis Kemiskinan Anak dan Deprivasi Hak-Hak Dasar Anak di Indonesia. Jakarta: Badan Pusat Statistik.

Dewi, N. M. (2019). Pengaruh Karakteristik Kepala Rumah Tangga Terhadap Status Kemiskinan Anak di RW 02 Kelurahan Kampung Melayu Tahun 2019 [Skripsi]. Jakarta: Sekolah Tinggi Ilmu Statistik.

Hosmer, David, W., Lemeshow, Stanley., Sturdivant, R. X. (2013). Applied Logistic Regr ession ( $3^{\text {nd }}$ ed). New York: John W illey and Sons Inc.

Junaidi, Irdina (2019). Analisis Status Kemiskinan Moneter dan Multidimensi Rumah Tangga KRT Laki-Laki di Provinsi Maluku Utara Tahun 2017 [Skripsi]. Jakarta: Sekolah Tinggi Ilmu Statistik.

Kumala, A. Z., Agustini, H. N., \& Rais. (2013). Dinamika Kemiskinan dan Pengukuran Kerentanan Kemiskinan dalam Upaya Melindungi Anak-anak dari Dampak Kemiskinan (Studi Kasus pada Rumah Tangga di Pulau Jawa Tahun 2008-2010). SMERU Research Institute.

Ramadhani, A. W., \& Munandar, A. I. (2019). Determinan Kemiskinan Anak di Provinsi DKI Jakarta: Susenas 2017. Jurnal Ekonomi Kuantitatif Terapan, 111-123.

Sari, E. N. (2018). Pengaruh Status Perkawinan Dan Kondisi Ekonomi Rumah Tangga Terhadap Kemiskinan Anak Di Provinsi Banten Tahun 2017. Judul Naskah JPKS Yogyakarta.

Smay, S. P. (2017). Analisis Status Kemiskinan Anak di Provinsi Papua Tahun 2015 dengan Metode Regresi Logistik Biner [Skripsi]. Jakarta: Sekolah Tinggi Ilmu Statistik.

Todaro, Michael P. 2000. Pembangunan Ekonomi di Dunia Ketiga. Bumi Aksara. Jakarta

Usman, H., Agustina, N., \& Parwanto, N. B. (2019). The Role Of Society Power In Reducing Poverty. An Article in $2^{\text {th }}$ International Conference on Research in Humanities, 22-24 November 2019. Paris

UU No. 35 tahun 2014." Badan Pembinaan Hukum Nasional. Diakses pada tanggal 2 Juni 2021 melalui. $\langle$ https://www.bphn.go.id/data/documents/14uu035.pdf $>$

Word Bank Institute. (2005). Introduction to Poverty Analysis . Washington DC: Word Bank Group. 